\title{
Stem Cell Self-Renewal and Cancer Cell Proliferation Are Regulated by Common Networks That Balance the Activation of Proto-oncogenes and Tumor Suppressors
}

\author{
R. PARdal, * A.V. Molofsky, S. He, ANd S.J. MorRison \\ Howard Hughes Medical Institute and Departments of Internal Medicine and Cell and \\ Developmental Biology, University of Michigan, Ann Arbor, Michigan 48109-0934
}

\begin{abstract}
Networks of proto-oncogenes and tumor suppressors that control cancer cell proliferation also regulate stem cell self-renewal and possibly stem cell aging. Proto-oncogenes promote regenerative capacity by promoting stem cell function but must be balanced with tumor suppressor activity to avoid neoplastic proliferation. Conversely, tumor suppressors inhibit regenerative capacity by promoting cell death or senescence in stem cells. For example, the polycomb family proto-oncogene, Bmi-1, is consistently required for the self-renewal of diverse adult stem cells, as well as for the proliferation of cancer cells in the same tissues. Bmi-1 promotes stem cell self-renewal partly by repressing the expression of Ink4a and Arf, tumor suppressor genes that are commonly deleted in cancer. Despite ongoing Bmi-1 expression, Ink $4 a$ expression increases with age, potentially reducing stem cell frequency and function. Increased tumor suppressor activity during aging therefore may partly account for age-related declines in stem cell function. Thus, networks of proto-oncogenes and tumor suppressors have evolved to coordinately regulate stem cell function throughout life. Imbalances within such networks cause cancer or premature declines in stem cell activity that resemble accelerated aging.
\end{abstract}

Mammals depend on stem cells in diverse tissues to replace cells throughout adult life and to repair tissues after injury or disease. For example, hematopoietic stem cells in the bone marrow produce millions of new blood cells daily, and stem cells in intestinal crypts constantly replace diverse types of gut epithelial cells. The depletion of stem cells from critical adult tissues, such as the hematopoietic system or gut epithelium, quickly leads to a loss of tissue integrity and death (for review, see Joseph and Morrison 2005). The persistence of stem cells throughout life in diverse tissues is therefore essential. The mechanism by which stem cells persist throughout life involves self-renewal, the process by which stem cells divide to form more stem cells (Morrison et al. 1997; Molofsky et al. 2004).

The persistence and continued mitotic activity of stem cells throughout life makes these cells a potential reservoir for the accumulation of oncogenic mutations (Reya et al. 2001). The self-renewal mechanisms that allow stem cells to persist consistently involve proto-oncogenic pathways such as Wnt, Shh, and Notch (Reya et al. 2001; Taipale and Beachy 2001). The activation of these pathways in stem cells throughout life may predispose these cells to neoplastic transformation, as it may take fewer mutations to constitutively activate such pathways in stem cells as compared to postmitotic cells in which pathway components are no longer expressed. There is evidence that some cancers arise from mutations that transform stem cells; however, the target cells for most cancers have not been rigorously identified, and many cancers may be capable of arising either from mutated

*Present address: Laboratorio de Investigaciones Biomédicas, Departamento de Fisiología and Hospital Universitario Virgen del Rocío, Universidad de Sevilla, E-41013, Seville, Spain. stem cells or from restricted progenitors/differentiated cells that acquire self-renewal capacity as a result of mutations (Sell and Pierce 1994; Reya et al. 2001; Pardal et al. 2003). In either case, the danger of neoplastic transformation from mutations that constitutively activate self-renewal pathways makes it critical to incorporate tumor suppressor mechanisms into this process.

Tumor suppressors come in two varieties: "caretakers," such as ATM (ataxia telangiectasia mutated), that prevent mutations by detecting and promoting the repair of DNA damage, and "gatekeepers," such as Rb and p53, that promote senescence or cell death when cells become mutated or stressed (Kinzler and Vogelstein 1997; Campisi 2005). Cellular senescence is a specialized form of terminal differentiation that is induced at the end of the replicative life of a cell, making the cell irreversibly postmitotic. These tumor suppressor functions take on added importance in stem cells as any mutations that occur in highly proliferative stem cells could be propagated throughout large numbers of progeny, increasing the probability of accumulating the additional mutations required for neoplastic transformation. Caretaker tumor suppressors would be expected to sustain normal stem cell activity by reducing the rate of mutagenesis. In contrast, gatekeeper tumor suppressors would be expected to reduce stem cell function by promoting cell death or senescence. Caretaking and gatekeeping tumor suppressors would thus be expected to have opposing effects on stem cell maintenance.

Tumor suppressors are also likely to influence stem cell aging. Tumor suppressors can induce cellular senescence in response to a variety of stimuli, including telomere shortening, oxidative stress, and oncogene activationeach of which activates tumor suppressors (Lowe and Sherr 2003; Itahana et al. 2004; Campisi 2005). Although the relationship between cellular senescence (which is typ- 
ically studied in vitro) and aging is not clear, it is thought that cellular senescence reflects some of the changes that occur during aging (Chang et al. 2004; Campisi 2005). Senescent cells have been reported to accumulate in aging human skin (Dimri et al. 1995), primate retina (Mishima et al. 1999), and human liver (Paradis et al. 2001). Senescent cells have also been detected at sites of age-related pathology (Vasile et al. 2001), and genes that overcome senescence can enhance the regenerative capacity of tissues exposed to chronic injury (Rudolph et al. 2000). These observations suggest that the senescence of progenitors in aging or damaged tissues may contribute to the age-related decline in the regenerative capacity of tissues.

The foregoing suggests that we have struck an evolutionary balance between proto-oncogenes that promote regeneration but also contribute to neoplastic proliferation, and tumor suppressors that inhibit carcinogenesis but also limit regenerative capacity. This raises the question of whether these pathways are coordinately regulated in stem cells, which are required for the regeneration of adult tissues, and which are thought to frequently be the targets of transforming mutations. Furthermore, aging is associated with decreased capacity for repair, increased incidence of degenerative disease, and increased incidence of cancer in many tissues that contain stem cells. This raises the additional question of whether the effects of proto-oncogenes and tumor suppressors on stem cells at least partially explain the changes observed in mammalian tissues with age. Recent evidence suggests that networks of proto-oncogenes and tumor suppressors coordinately regulate self-renewal and age-related changes in stem cells, as well as the generation and proliferation of cancer cells in the same tissues. This indicates that common networks of genes regulate stem cell self-renewal, cancer cell proliferation, and stem cell aging.

\section{Bmi-1 PROMOTES STEM CELL SELF-RENEWAL AND CANCER CELL PROLIFERATION}

Bmi-1 was first identified in 1991 as a proto-oncogene that cooperates with c-myc in oncogenesis (Haupt et al. 1991; van Lohuizen et al. 1991) and that causes leukemia when overexpressed in mice (Haupt et al. 1993). It is a member of the Polycomb group of proteins, transcriptional repressors that modify chromatin structure in a heritable way to maintain gene expression patterns established during prenatal development (Valk-Lingbeek et al. 2004). It has since been found to be overexpressed in multiple human cancers, including mantle cell lymphomas (Bea et al. 2001), non-small-cell lung cancer (Vonlanthen et al. 2001), and medulloblastomas (Leung et al. 2004).

Bmi-1-deficient mice are born in normal numbers and appear normal except for a relatively mild skeletal patterning abnormality (van der Lugt et al. 1994) that is presumably caused by the dysregulation of Hox gene expression upon loss of Bmi-1 (Alkema et al. 1995). In contrast to their nearly normal prenatal development, $B m i-1^{-1-}$ mice exhibit progressive growth retardation postnatally and typically die by early adulthood with hematopoietic failure, and neurological abnormalities including ataxia and seizures (van der Lugt et al. 1994).

The onset of growth retardation, hematopoietic failure, and neurological abnormalities correlates with the depletion of stem cells from every adult tissue yet examined in Bmi-1-deficient mice. Stem cells in the hematopoietic system and in the central and peripheral nervous systems form in normal numbers in the absence of Bmi-1, and appear to differentiate normally during fetal development, but exhibit a postnatal self-renewal defect that leads to their depletion by early adulthood (Fig. 1) (Lessard and Sauvageau 2003; Molofsky et al. 2003; Park et al. 2003). Overexpression of Bmi-1 is also sufficient to promote the self-renewal of hematopoietic stem cells (Iwama et al. 2004). Interestingly, some restricted neural progenitors from the forebrain and gut proliferate normally in the absence of Bmi-1, indicating that $B m i-1$ is not generically required for the proliferation of all cells (Molofsky et al. 2003). These results indicate that $B m i-1$ is preferentially and consistently required for the postnatal maintenance of stem cells.

In addition to being essential for the maintenance of adult stem cells, Bmi- 1 is similarly required for the maintenance of cancer stem cells (Reya et al. 2001; Pardal et al. 2003). It is required for the maintenance of leukemic stem cells in a manner very similar to its requirement for the maintenance of normal hematopoietic stem cells (Lessard and Sauvageau 2003), and it is likely to be required for the proliferation of medulloblastoma cells as well (Leung et al. 2004). Bmi-1 overexpression also promotes the generation/maintenance of cancer cells, as Bmi-1 overexpression in lymphocytes leads to lymphoma (Haupt et al. 1993) and, in mammary epithelial cells, leads to their immortalization (Dimri et al. 2002). These data support the idea that cancer cells generally, and cancer stem cells in particular, depend on similar pathways as normal stem cells for their proliferation/self-renewal.

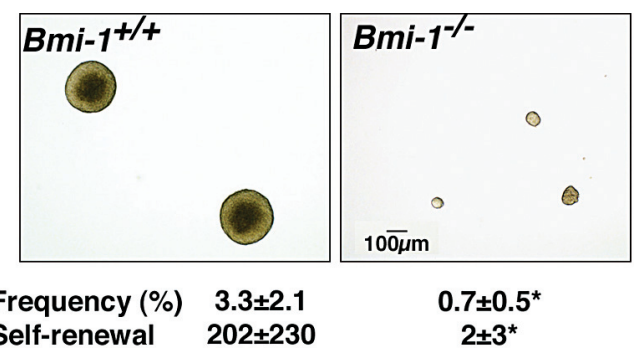

Figure 1. CNS stem cells require Bmi-1 to self-renew postnatally. The photos depict typical neurospheres (neural stem cell colonies that arise from single cells in nonadherent cultures) that formed after 10 days in culture from CNS subventricular zone cells. By postnatal day 30 , the frequency of CNS subventricular zone cells that formed multipotent neurospheres in culture was significantly lower in the absence of Bmi-1, and the self-renewal of these cells in culture was also significantly reduced $(*, p<$ 0.05 ). Self-renewal is expressed as the number of secondary neurospheres generated per primary neurosphere upon subcloning. Similar results were obtained for multipotent neural crest stem cells from the peripheral nervous system (data not shown). (Photos reprinted, with permission, from Molofsky et al. 2003 [@Nature Publishing Group].) 


\section{OTHER PROTO-ONCOGENES ALSO PROMOTE STEM CELL SELF-RENEWAL}

$\mathrm{Bmi}-\mathrm{I}$ is not unusual among proto-oncogenes in promoting the self-renewal of normal stem cells and the proliferation of cancer cells from the same tissues (Reya et al. 2001). The Wnt/ $\beta$-catenin signaling pathway promotes the self-renewal of intestinal epithelial stem cells, and mutations that increase signaling through this pathway promote the generation and proliferation of colorectal cancer cells (Kinzler and Vogelstein 1996; Batlle et al. 2002; van de Wetering et al. 2002). This pathway also promotes normal stem cell self-renewal and tumorigenesis in other tissues, including the skin and the hematopoietic system (for review, see Kleber and Sommer 2004; Reya and Clevers 2005). Similarly, Sonic Hedgehog signaling is necessary for the maintenance of neural stem cells in the central nervous system (Lai et al. 2003; Machold et al. 2003), and overactivation of this pathway is involved in the generation of diverse types of brain tumors (Ruiz i Altaba et al. 2002). These are only a few of many examples of pathways that promote normal stem cell self-renewal and which lead to tumorigenesis upon overactivation. These results are consistent with the idea that mutations frequently cause cancer by inappropriately activating selfrenewal mechanisms in stem cells or other cells.

\section{THE TUMOR SUPPRESSORS Ink4a AND Arf INHIBIT CANCER CELL PROLIFERATION AND STEM CELL SELF-RENEWAL}

To avoid neoplastic proliferation, the activities of proto-oncogenes are balanced against tumor suppressors. Tumor suppressor activity can be induced by inappropriate mitogenic stimuli and can inhibit proliferation by promoting cellular senescence or cell death. The Ink4a-Arf locus encodes two gatekeeper tumor suppressors that activate critical senescence pathways (Sherr 2001; Campisi 2005). Ink $4 a$ encodes $16^{\text {Ink } 4 a}$, a cyclin-dependent kinase inhibitor that promotes $\mathrm{Rb}$ activation by disrupting cyclin D-cdk4/6 complexes. Arf encodes p19 Arf, which promotes p53 activation by inactivating Mdm2. Induction of p $16^{\text {Ink4a }}$ and/or p19 ${ }^{\text {Arf }}$ expression in cultured primary cells leads to cellular senescence via the activation of these $\mathrm{Rb}$ and $\mathrm{p} 53$ pathways (for review, see Campisi 2005). Bmi-1 overexpression, in contrast, can bypass senescence and extend the replicative life span of primary cells by reducing $\mathrm{p} 16^{\text {Ink4a }}$ and $\mathrm{p} 19^{\text {Arf }}$ expression (Jacobs et al. 1999a; Dimri et al. 2002; Itahana et al. 2003).

Inactivation of these senescence pathways contributes strongly to carcinogenesis. Ink $4 a$ deletion in mice and humans is associated with lymphoma, lung adenoma, brain tumors, melanoma, and other cancers (Krimpenfort et al. 2001; Sharpless et al. 2001; Sherr and McCormick 2002). Arf deletion in mice leads to an increased incidence of sarcomas, lymphomas, and gliomas, as well as other types of cancers (Kamijo et al. 1999). Combined loss of Ink4a and Arf is often observed in human tumors (for review, see Ruas and Peters 1998; Sherr 1998). These data indicate that $\mathrm{p} 16^{\mathrm{Ink} 4 \mathrm{a}}$ and $\mathrm{p} 19^{\text {Arf }}$ are critical tumor suppressors in diverse tissues. $\mathrm{p} 16^{\text {Ink4a }}$ and $\mathrm{p} 19^{\text {Arf }}$ also inhibit the self-renewal of at least some types of stem cells. Two of the major mechanisms by which Bmi-1 promotes neural stem cell self-renewal are inhibiting Ink4a and Arf expression (Molofsky et al. 2003, 2005; Bruggeman et al. 2005). Bmi-1 directly or indirectly represses transcription at the Ink4a-Arflocus (Jacobs et al. 1999a, b; Itahana et al. 2003). Deletion of Ink4aArf rescues the ability of $B m i-1^{-/}$mouse embryonic fibroblasts to proliferate in culture and partially rescues cerebellum development in $B m i-1^{-/}$mice (Jacobs et al. 1999a). Although p $16^{\text {Ink4a }}$ and $\mathrm{p} 19^{\text {Arf }}$ are not generally expressed by normal cells in young mice in vivo (Zindy et al. 1997), these proteins become strongly expressed in stem cells and other progenitors in the absence of Bmi-1 (Molofsky et al. 2003, 2005; Park et al. 2003). Deletion of either Ink4a or Arf from Bmi-1-deficient mice substantially, although only partially, rescues neural stem cell self-renewal, neural stem cell frequency, and various aspects of
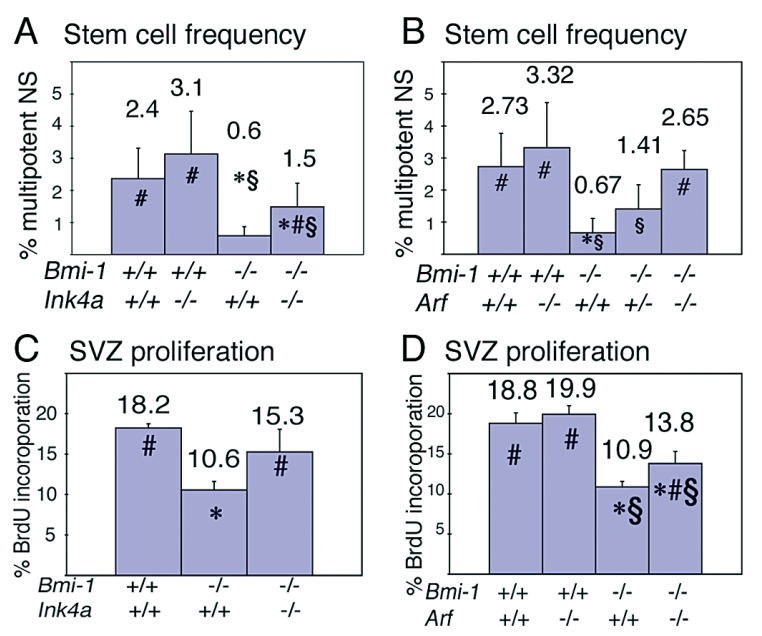

E Cerebellum Size

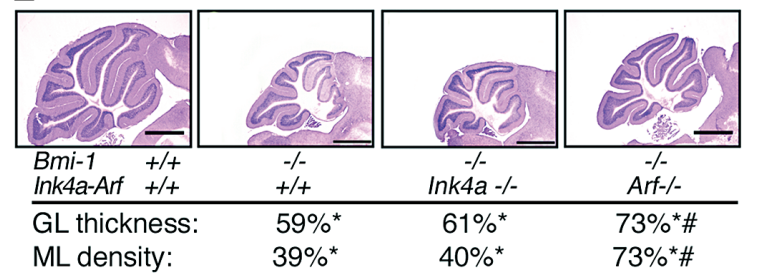

Figure 2. Deletion of Ink4a or Arf significantly rescues stem cell frequency and proliferation in the forebrain subventricular zone (SVZ) of Bmi-1 $1^{-1-}$ mice but exhibits differential effects on cerebellum rescue. Ink4a deficiency $(A)$ or $A r f$ deficiency $(B)$ partially rescues the percentage of SVZ cells from $B m i-1^{-1-}$ mice that form multipotent stem cell colonies in culture. The rate of proliferation (percentage of cells that incorporate a pulse of $\mathrm{BrdU})$ in the forebrain SVZ of $B m i-1^{-1-}$ mice is also significantly increased by Ink $4 a$ deficiency $(C)$ or by $\operatorname{Arf}$ deficiency $(D)$. $(E)$ Hematoxylin and eosin-stained sagittal sections of adult cerebellum show that deletion of $A r f$, but not Ink $4 a$, partially rescues the overall cerebellum size in $B m i-1^{-/-}$mice. Thickness of the cerebellum granule cell layer (GL) and cell density in the molecular layer (ML) for each genotype is quantified as a percentage of wild-type. * indicates significantly different $(p<0.05$ by $t$ test) from wild-type, \# indicates significantly different from $B m i-1^{-/} I n k 4 a^{+/+}$or $B m i-1^{-1} A r f^{+/+}$, and $\S$ indicates significantly different from Bmi-1 ${ }^{+/+}$Ink $4 a^{-/-}$or Bmi- ${ }^{+/+} \mathrm{Arf}^{/-}$. 


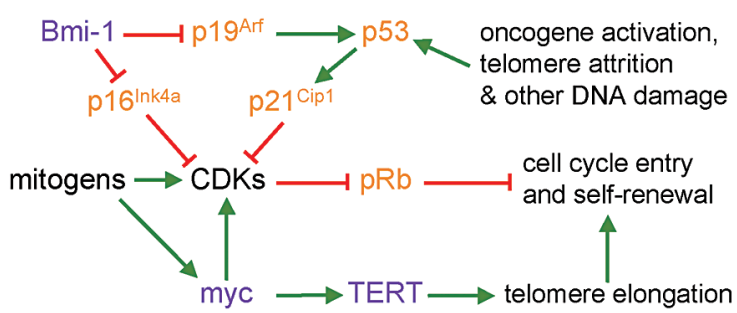

Figure 3. Networks of proto-oncogenes (purple) and tumor suppressors (orange) control stem cell self-renewal. The ability of adult stem cells to self-renew depends on a network of protooncogenes that activate cell cycle entry, and tumor suppressors that block cell cycle progression. External stimuli like mitogen activation promote cell cycle entry, whereas oncogene activation, telomere attrition, or DNA damage can promote senescence or cell death via p53 activation.

neural development (Fig. 2) (Molofsky et al. 2003, 2005; Bruggeman et al. 2005). These results indicate that the Ink4a and $A r f$ senescence pathways must be repressed in order to maintain neural stem cells throughout adult life. Adult stem cell self-renewal thus reflects a balance in which proto-oncogene activity promotes self-renewal and tumor suppressor activity inhibits self-renewal (Fig. 3). Mutational overactivation of proto-oncogenes can cause cancer, whereas substantial increases in tumor suppressor activity can cause premature senescence of stem cells, potentially impairing tissue growth and regeneration (Fig. 4).

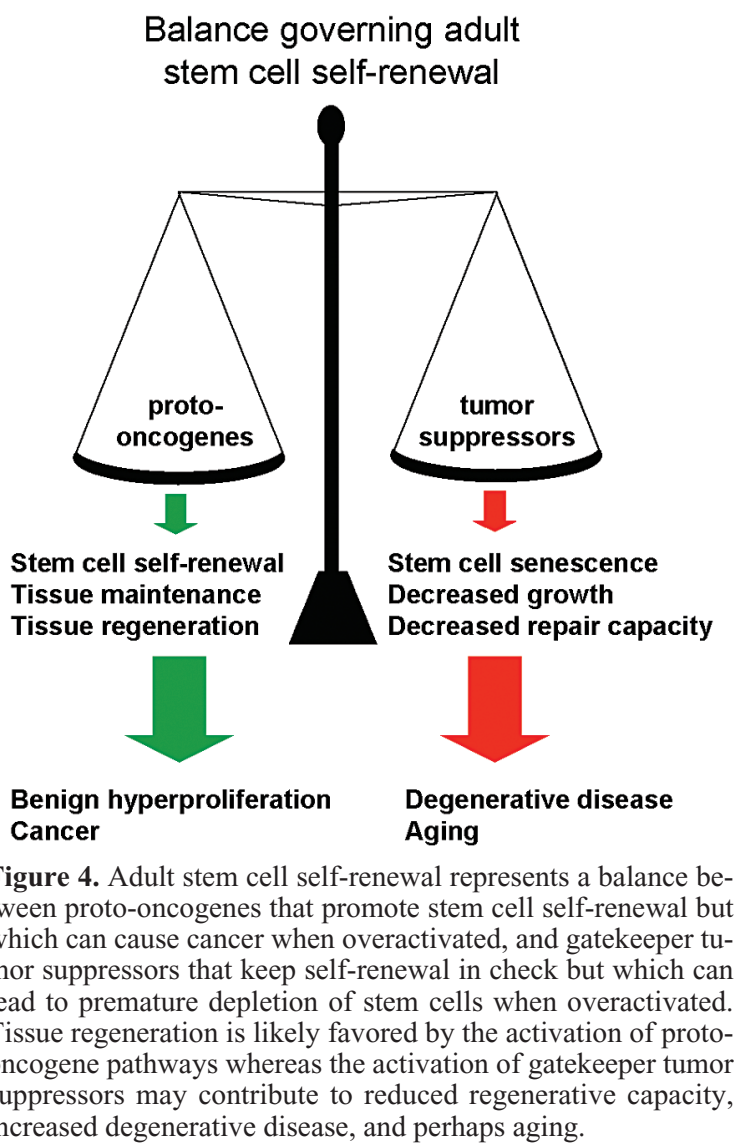

\section{THE Ink4a TUMOR SUPPRESSOR MAY ALSO PROMOTE STEM CELL AGING}

A central feature of aging in mammals is the reduced capacity for regeneration in tissues that contain stem cells. Stem cell function declines with age in diverse tissues, including the hematopoietic system (Morrison et al. 1996b; Chen et al. 2000), muscle (Conboy et al. 2003, 2005), and brain (Kuhn et al. 1996; Maslov et al. 2004). Indeed, differences among mouse strains in the frequency and proliferation of hematopoietic stem cells during aging correlate with differences in life span, suggesting that stem cell aging is regulated by mechanisms that also determine life span (de Haan et al. 1997). These observations raise the possibility that certain aspects of mammalian aging are caused by age-related reductions in stem cell function.

The expression of $\mathrm{p} 16^{\mathrm{Ink} 4 \mathrm{a}}$ and $\mathrm{p} 19^{\text {Arf }}$ increases substantially with age in multiple mouse tissues (Zindy et al. 1997; Krishnamurthy et al. 2004). This raises the question of whether these increases in $\mathrm{p} 16^{\text {Ink4a }}$ and $\mathrm{p} 19^{\mathrm{Arf}} \mathrm{ex}-$ pression cause age-related declines in tissue function (Sharpless 2004). Although moderately increased expression of $\mathrm{p} 16^{\text {Ink4a }}$ and $\mathrm{p} 19^{\text {Arf }}$ in transgenic mice did not detectably accelerate aging or change life span (Matheu et al. 2004), the increase in $\mathrm{p} 16^{\mathrm{Ink} 4 \mathrm{a}}$ and $\mathrm{p} 19^{\mathrm{Arf}}$ expression in these mice was small relative to the increase observed in old mice. The levels of $\mathrm{p} 16^{\text {Ink4a }}$ and $\mathrm{p} 19^{\text {Arf }}$ that are required to promote aging may be qualitatively higher than the levels that are required to inhibit cancer. To assess the physiological role of these proteins in normal aging, it will therefore be necessary to examine mice that are deficient for Ink4a and/or Arf (Fig. 5).

Although Ink4a may regulate stem cell aging, the relationship between stem cell aging and overall organismal aging or life span remains unclear. The age-related decline in stem cell function may be a major cause of the decline in regenerative capacity and the increase in degenerative disease that are observed in many aging tissues. On the other hand, increases in the death or dysfunction of mature cells in many aging tissues must also contribute to age-related morbidity. It is similarly unknown whether physiological differences in the rate at which stem cell activity declines with age have a detectable impact on longevity. It is likely that there will be important differences between tissues, and perhaps between stem cells and differentiated cells, in terms of the genes that regulate

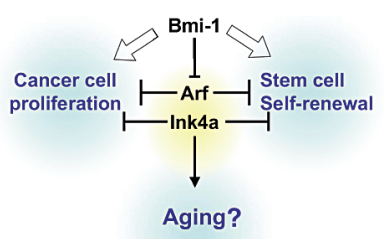

Figure 5. Stem cell self-renewal, stem cell aging, and cancer cell proliferation may be coordinately regulated by pathways that balance the activation of proto-oncogenes like Bmi-1 and tumor suppressors like Ink4a and Arf. 
the aging process. Although many of these big picture questions remain unanswered, it may be possible to gain important new insights into the aging process at a cellular level by studying individual cell types that have known physiological functions in vivo, such as hematopoietic or neural stem cells.

\section{OTHER TUMOR SUPPRESSORS MAY ALSO REGULATE AGING}

Other tumor suppressors also regulate aging in mice, although few studies have specifically examined their ability to promote age-related changes in stem cells. p53 is a powerful gatekeeping tumor suppressor that responds to a variety of cellular stresses, including DNA damage, hypoxia, and oncogene activation, to induce cell death or cell cycle arrest (Levine 1997; Serrano et al. 1997; Giaccia and Kastan 1998). p53 is also one of the most commonly deleted genes in human cancer (Lozano and Elledge 2000; Sherr and McCormick 2002). Recent reports about genetically engineered mice with altered longevity phenotypes implicate p53 as a mediator of aging (Migliaccio et al. 1999; Vogel et al. 1999; Lim et al. 2000). Mice expressing a mutant form of p53 that augments wild-type p53 activity exhibit enhanced resistance to spontaneous tumors and display an early onset of phenotypes associated with aging (Tyner et al. 2002). The short isoform of p53, p44, promotes IGF-1 signaling (Maier et al. 2004), a pathway that controls both aging and cancer cell proliferation in mammals (Holzenberger et al. 2003; Pollak et al. 2004). Mice overexpressing p44 exhibit phenotypes consistent with accelerated aging (Maier et al. 2004). Moderate overexpression of p53 in BAC transgenic mice increased cancer resistance but did not accelerate aging (Garcia-Cao et al. 2002), suggesting that aging requires higher levels of p53 activity than tumor suppression. This raises the question of whether physiological levels of p53 expression regulate aging; the levels of p53 activation that are required to accelerate aging may never be achieved under physiological circumstances. Nonetheless, p53 is likely to regulate the self-renewal of stem cells because p53 activation promotes $\mathrm{p} 21^{\mathrm{Cip} 1}$ expression, and $\mathrm{p} 21^{\mathrm{Cip} 1}$ regulates stem cell self-renewal in diverse tissues (Cheng et al. 2000; Kippin et al. 2005).

Telomere length is another crucial checkpoint that regulates neoplastic proliferation, as well as stem cell function and aging (Sharpless and DePinho 2004). Telomeres are repetitive DNA sequences at the ends of eukaryotic chromosomes that prevent the fusion of chromosomes (McEachern et al. 2000). In most somatic tissues, telomeric DNA undergoes progressive shortening with each round of cell division, resulting from incomplete replication by DNA polymerases (McEachern et al. 2000). Telomere shortening to a critical length can activate DNA damage pathways that trigger cell cycle arrest or apoptosis (Chiu and Harley 1997). Thus, telomere attrition limits the number of times that progenitors can divide in the absence of mechanisms like telomerase expression that maintain or lengthen telomeres.

Stem cells express telomerase and depend on it to maintain their tremendous self-renewal potential (Morrison et al. 1996a; Lee et al. 1998; Allsopp et al. 2003a); however, telomere length in stem cells still declines with age and can limit stem cell proliferation after repeated injury (Chiu et al. 1996; Rudolph et al. 2000; Allsopp et al. 2003b). Inbred laboratory mice have hyper-long telomeres (Starling et al. 1990) and therefore take three generations to critically deplete telomeres in the absence of telomerase; however, upon reaching this point, telomerase-deficient mice exhibit proliferation defects in a variety of tissues and show signs of premature aging (Blasco et al. 1997; Lee et al. 1998). These phenotypes are rescued to a considerable extent by p53 deficiency, indicating that telomere attrition causes senescence via p53 activation (Chin et al. 1999). By regulating the number of times a cell can divide before triggering senescence, telomeres and telomerase can inhibit neoplastic proliferation and determine the replicative life span of normal stem cells. Since humans have a much longer life span and much shorter telomeres than inbred mice, these observations raise the possibility that the proliferation of some human cells could be limited by telomere erosion during normal aging in vivo.

Although gatekeeper tumor suppressors promote aging phenotypes, other tumor suppressors can slow the aging process while linking stem cell self-renewal and cancer cell proliferation. ATM is a caretaker tumor suppressor that is activated in response to oxidative stress, DNA damage, or telomere instability, and which can promote DNA damage repair as well as cellular senescence (Shiloh 2003). Mutational inactivation of Atm causes ataxia telangiectasia, a recessive disorder characterized by neuronal degeneration, premature aging, and high cancer incidence (Shiloh 2003). Loss of both Atm and telomerase function in mice leads to premature aging with multiple stem cell populations apparently affected (Wong et al. 2003). ATM also regulates the maintenance of hematopoietic stem cells (Ito et al. 2004). In the absence of Atm, an increase in reactive oxygen species leads to activation of $\mathrm{p} 16^{\text {ink4a }}$ and to the depletion of hematopoietic stem cells, which could be rescued by treatment with antioxidants or by overexpression of Bmi-1. ATM therefore slows the aging process and avoids carcinogenesis by reducing DNA damage and other oxidative damage in diverse cells, including stem cells.

The tumor suppressor PTEN negatively regulates signaling through the PI3 kinase pathway, which promotes cell growth, proliferation, and survival (Stiles et al. 2004). PTEN negatively regulates the self-renewal of fetal CNS stem cells (Backman et al. 2001; Groszer et al. 2001) as well as the proliferation of CNS and other cancer cells (Suzuki et al. 1998; Di Cristofano and Pandolfi 2000; Wechsler-Reya and Scott 2001). PTEN negatively regulates signaling through the insulin/insulin-like growth factor pathway, which promotes aging in an evolutionarily conserved manner (Tatar et al. 2003), and the Caenorhabditis elegans homolog of Pten, Daf-18, promotes life span extension in nematodes (Mihaylova et al. 1999; Solari et al. 2005). Human Pten complements the Daf-18 mutation in worms (Solari et al. 2005), raising the 
question of whether PTEN promotes life span extension, or at least maintenance of adult stem cell activity, in mammals as well.

\section{CONCLUSIONS: AN EVOLVED BALANCE BETWEEN PROTO-ONCOGENES AND TUMOR SUPPRESSORS}

Stem cells must self-renew throughout life to promote tissue maintenance and repair. This makes these cells particularly susceptible to the accumulation of potentially transforming mutations. To promote tissue regeneration while avoiding malignant transformation, a tightly regulated balance between the expression of proto-oncogenes and tumor suppressors has evolved. Proto-oncogenes promote stem cell self-renewal and tissue regeneration, but mutations that activate these pathways can lead to cancer. Gatekeeping tumor suppressors are activated by mutations and prevent neoplastic proliferation by promoting cellular senescence. This reduces cancer incidence but also contributes to aging by reducing the regenerative capacity of tissues. Hence, aging is in some ways a by-product of mechanisms that evolved to prevent the neoplastic transformation of stem cells and other progenitors.

The balance of proto-oncogene and tumor suppressor activity in stem cells changes throughout life (Fig. 6). Fetal development is a time of rapid tissue growth before cells have an opportunity to accumulate mutations. As a result, proto-oncogene activity dominates tumor suppressor activity in stem cells during fetal development to promote rapid proliferation. In contrast, most adult stem cells are quiescent most of the time (Morshead et al. 1994; Cheshier et al. 1999). Whereas this quiescence is likely critical for stem cell maintenance and probably reflects the increased influence of tumor suppressors during adult life (Cheng et al. 2000), the regulation of stem cell quies-

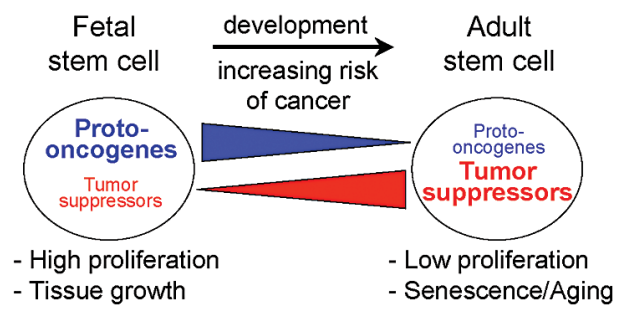

Figure 6. Developmental changes in the balance between protooncogenes and tumor suppressors. Stem cells proliferate rapidly during fetal development to accomplish the necessary tissue growth. This suggests that pathways which favor proliferation are strongly activated during fetal development and may not be subject to some of the gatekeeping tumor suppressor mechanisms that limit the proliferation of adult cells. Evolutionarily it may be possible to promote rapid fetal growth by removing tumor suppressor mechanisms because there is little opportunity to accumulate carcinogenic mutations during fetal development. In contrast, adult stem cells are quiescent most of the time, and appear to be subject to many more constraints upon their rate and extent of proliferation. This suggests that more tumor suppressor mechanisms are expressed in adult cells, which are at risk of accumulating transforming mutations. cence remains poorly understood. In concert with these developmental changes in stem cell function, adult mammals also exhibit an increased incidence of cancer in all proliferative tissues that contain stem cells. Whether because of accumulating damage/dysfunction or because of a developmentally programmed senescence process, tumor suppressors such as p16 $6^{\text {Ink4a }}$ appear to exhibit increasing activity in aging stem cells. This could contribute to age-related morbidity by reducing the regenerative capacity of aging tissues, perhaps increasing the incidence of degenerative disease.

These observations raise the question of whether polymorphisms that cause partial increases or decreases in the activity of proto-oncogenes and tumor suppressors cause physiological variations in tissue regenerative capacity or aging just as such polymorphisms are already known to affect cancer predisposition. A human polymorphism that reduces p53 activity increases cancer risk but may also be associated with significantly increased survival into old age, despite the increased cancer risk (van Heemst et al. 2005). More studies confirming findings of this type could greatly increase our understanding of how relatively small functional changes in tumor suppressor function could lead to natural variations in human longevity and regenerative capacity (Donehower 2005). A key question is whether by better understanding these networks of proto-oncogenes and tumor suppressors it will be possible to pharmacologically enhance tissue regeneration or delay changes associated with aging without increasing the risk of cancer and vice versa.

\section{ACKNOWLEDGMENTS}

This work was supported by the National Institutes of Health (R01 NS40750), the James S. McDonnell Foundation, and the Howard Hughes Medical Institute. R.P. was supported by a postdoctoral fellowship from the Spanish Ministry of Science and Technology but is now a Ramon y Cajal Fellow at the University of Seville. A.V.M. was supported by a National Research Service Award from the National Institutes of Health (F30 NS048642). S.H. was supported by a fellowship from the University of Michigan Cellular and Molecular Biology program. Thanks to Maarten van Lohuizen for providing $B m i-1^{+/-}$mice, to Charles Sherr for providing $A r f^{+/-}$mice, and to Ronald DePinho for providing Ink4a $\mathrm{a}^{+-}$and Ink4a-Arf ${ }^{+/-}$mice.

\section{REFERENCES}

Alkema M.J., van der Lugt N.M.T., Bobeldijk R.C., Berns A., and van Lohuizen M. 1995. Transformation of axial skeleton due to overexpression of bmi-1 in transgenic mice. Nature 374: 724.

Allsopp R.C., Morin G.B., DePinho R., Harley C.B., and Weissman I.L. 2003a. Telomerase is required to slow telomere shortening and extend replicative lifespan of HSCs during serial transplantation. Blood 102: 517.

Allsopp R.C., Morin G.B., Horner J.W., DePinho R., Harley C.B., and Weissman I.L. 2003b. Effect of TERT over-expression on the long-term transplantation capacity of hematopoietic stem cells. Nat. Med. 9: 369.

Backman S.A., Stambolic V., Suzuki A., Haight J., Elia A., Pretorius J., Tsao M.-S., Shannon P., Bolon B., Ivy G.O., and 
Mak T.W. 2001. Deletion of Pten in mouse brain causes seizures, ataxia, and defects in soma size resembling Lhermitte-Duclos disease. Nat. Genet. 29: 396.

Batlle E., Henderson J.T., Beghtel H., van den Born M.M., Sancho E., Huls G., Meeldijk J., Robertson J., van de Wetering M., Pawson T., and Clevers H. 2002. Beta-catenin and TCF mediate cell positioning in the intestinal epithelium by controlling the expression of EphB/ephrinB. Cell 111: 251.

Bea S., Tort F., Pinyol M., Puig X., Hernandez L., Hernandez S., Fernandez P.L., van Lohuizen M., Colomer D., and Campo E. 2001. BMI-1 gene amplification and overexpression in hematological malignancies occur mainly in mantle cell lymphomas. Cancer Res. 61: 2409.

Blasco M.A., Lee H.-W., Hande M.P., Samper E., Lansdorp P.M., DePinho R.A., and Greider C.W. 1997. Telomere shortening and tumor formation by mouse cells lacking telomerase RNA. Cell 91: 25.

Bruggeman S.W.M., Valk-Lingbeek M.E., van der Stoop P.P.M., Jacobs J.J.L., Kieboom K., Tangier E., Hulsman D., Leung C., Arsenijevic Y., Marino S., and van Lohuizen M. 2005. Ink4a and Arf differentially affect cell proliferation and neural stem cell self-renewal in Bmi-1-deficient mice. Genes Dev. 19: 1438.

Campisi J. 2005. Senescent cells, tumor suppression, and organismal aging: Good citizens, bad neighbors. Cell 120: 513.

Chang S., Multani A.S., Cabrera N.G., Naylor M.L., Laud P., Lombard D., Pathak S., Guarente L., and DePinho R.A. 2004. Essential role of limiting telomeres in the pathogenesis of Werner syndrome. Nat. Genet. 36: 877.

Chen J., Astle C.M., and Harrison D.E. 2000. Genetic regulation of primitive hematopoietic stem cell senescence. Exp. Hematol. 28: 442

Cheng T., Rodrigues N., Shen H., Yang Y.-G., Dombkowski D., Sykes M., and Scadden D.T. 2000. Hematopoietic stem cell quiescence maintained by p21cip1/waf1. Science 287: 1804 .

Cheshier S., Morrison S.J., Liao X., and Weissman I.L. 1999. In vivo proliferation and cell cycle kinetics of long-term self-renewing hematopoietic stem cells. Proc. Natl. Acad. Sci. 96: 3120 .

Chin L., Artandi S.E., Shen Q., Tam A., Lee S.L., Gottlieb G.J., Greider C.W., and DePinho R.A. 1999. p53 deficiency rescues the adverse effects of telomere loss and cooperates with telomere dysfunction to accelerate carcinogenesis. Cell 97: 527.

Chiu C.P. and Harley C.B. 1997. Replicative senescence and cell immortality: The role of telomeres and telomerase. Proc. Soc. Exp. Biol. Med. 214: 99

Chiu C.-P., Dragowska W., Kim N.W., Vaziri H., Yui J., and Lansdorp P. 1996. Differential expression of telomerase activity in hematopoietic progenitors from adult human bone marrow. Stem Cells 14: 239.

Conboy I.M., Conboy M.J., Smythe G.M., and Rando T.A. 2003. Notch-mediated restoration of regenerative potential to aged muscle. Science 302: 1575.

Conboy I.M., Conboy M.J., Wagers A.J., Girma E.R., Weissman I.L., and Rando T.A. 2005. Rejuvenation of aged progenitor cells by exposure to a young systemic environment. Nature 433: 760 .

de Haan G., Nijhof W., and Van Zant G. 1997. Mouse strain-dependent changes in frequency and proliferation of hematopoietic stem cells during aging: Correlation between lifespan and cycling activity. Blood 89: 1543.

Di Cristofano A. and Pandolfi P.P. 2000. The multiple roles of PTEN in tumor suppression. Cell 100: 387.

Dimri G.P., Martinez J.L., Jacobs J.J., Keblusek P., Itahana K., van Lohuizen M., Campisi J., Wazer D.E., and Band V. 2002. The Bmi-1 oncogene induces telomerase activity and immortalizes human mammary epithelial cells. Cancer Res. 62: 4736.

Dimri G.P., Lee X., Basile G., Acosta M., Scott G., Roskelley C., Medrano E.E., Linskens M., Rubelj I., and Pereira-Smith O., et al. 1995. A biomarker that identifies senescent human cells in culture and in aging skin in vivo. Proc. Natl. Acad. Sci. 92: 9363.

Donehower L.A. 2005. p53: Guardian AND suppressor of longevity? Exp. Gerontol. 40: 7.
Garcia-Cao I., Garcia-Cao M., Martin-Caballero J., Criado L.M., Klatt P., Flores J.M., Weill J.C., Blasco M.A., and Serrano M. 2002. "Super p53" mice exhibit enhanced DNA damage response, are tumor resistant and age normally. EMBO J. 21: 6225 .

Giaccia A.J. and Kastan M.B. 1998. The complexity of p53 modulation: Emerging patterns from divergent signals. Genes Dev. 12: 2973.

Groszer M., Erickson R., Scripture-Adams D.D., Lesche R., Trumpp A., Zack J.A., Kornblum H.I., Liu X., and Wu H. 2001. Negative regulation of neural stem/progenitor cell proliferation by the Pten tumor suppressor gene in vivo. Science 294: 2186

Haupt Y., Bath M.L., Harris A.W., and Adams J.M. 1993. BMI1 transgene induces lymphomas and collaborates with Myc in tumorigenesis. Oncogene 8: 3161.

Haupt Y., Alexander W.S., Barri G., Klinken S.P., and Adams J.M. 1991. Novel zinc finger gene implicated as myc collaborator by retrovirally accelerated lymphomagenesis in E mumyc transgenic mice. Cell 65: 753.

Holzenberger M., Dupont J., Ducos B., Leneuve P., Geloen A., Even P.C., Cervera P., and Le Bouc Y. 2003. IGF-1 receptor regulates lifespan and resistance to oxidative stress in mice. Nature 421: 182.

Itahana K., Campisi J., and Dimri G.P. 2004. Mechanisms of cellular senescence in human and mouse cells. Biogerontology 5: 1.

Itahana K., Zou Y., Itahana Y., Martinez J.L., Beausejour C., Jacobs J.J., Van Lohuizen M., Band V., Campisi J., and Dimri G.P. 2003. Control of the replicative life span of human fibroblasts by $\mathrm{p} 16$ and the polycomb protein Bmi-1. Mol. Cell. Biol. 23: 389 .

Ito K., Hirao A., Arai F., Matsuoka S., Takubo K., Hamaguchi I., Nomiyama K., Hosokawa K., Sakurada K., Nakagata N., Ikeda Y., Mak T.W., and Suda T. 2004. Regulation of oxidative stress by ATM is required for self-renewal of haematopoietic stem cells. Nature 431: 997.

Iwama A., Oguro H., Negishi M., Kato Y., Morita Y., Tsukui H., Ema H., Kamijo T., Katoh-Fukui Y., Koseki H., van Lohuizen M., and Nakauchi H. 2004. Enhanced self-renewal of hematopoietic stem cells mediated by the polycomb gene product Bmi-1. Immunity 21: 843 .

Jacobs J.J., Kieboom K., Marino S., DePinho R.A., and van Lohuizen M. 1999a. The oncogene and Polycomb-group gene bmi-1 regulates cell proliferation and senescence through the ink4a locus. Nature 397: 164.

Jacobs J.J., Scheijen B., Voncken J.W., Kieboom K., Berns A., and van Lohuizen M. 1999b. Bmi-1 collaborates with c-Myc in tumorigenesis by inhibiting c-Myc-induced apoptosis via INK4a/ARF. Genes Dev. 13: 2678.

Joseph N.M. and Morrison S.J. 2005. Toward an understanding of the physiological function of stem cells. Dev. Cell 9: 173.

Kamijo T., Bodner S., van de Kamp E., Randle D.H., and Sherr C.J. 1999. Tumor spectrum in ARF-deficient mice. Cancer Res. 59: 2217.

Kinzler K.W. and Vogelstein B. 1996. Lessons from hereditary colorectal cancer. Cell 87: 159.

-1997. Cancer-susceptibility genes. Gatekeepers and caretakers. Nature 386: 761.

Kippin T.E., Martens D.J., and van der Kooy D. 2005. p21 loss compromises the relative quiescence of forebrain stem cell proliferation leading to exhaustion of their proliferation capacity. Genes Dev. 19: 756.

Kleber M. and Sommer L. 2004. Wnt signaling and the regulation of stem cell function. Curr. Opin. Cell Biol. 16: 681.

Krimpenfort P., Quon K.C., Mooi W.J., Loonstra A., and Berns A. 2001. Loss of p16Ink4a confers susceptibility to metastatic melanoma in mice. Nature 413: 83.

Krishnamurthy J., Torrice C., Ramsey M.R., Kovalev G.I., AlRegaiey K., Su L., and Sharpless N.E. 2004. Ink4a/Arf expression is a biomarker of aging. J. Clin. Invest. 114: 1299.

Kuhn H.G., Dickinson-Anson H., and Gage F.H. 1996. Neurogenesis in the dentate gyrus of the adult rat: Age-related decrease of neuronal progenitor proliferation. J. Neurosci. 16: 2027. 
Lai K., Kaspar B.K., Gage F.H., and Schaffer D.V. 2003. Sonic hedgehog regulates adult neural progenitor proliferation in vitro and in vivo. Nat. Neurosci. 6: 21 .

Lee H.-W., Blasco M.A., Gottlieb G.J., Horner J.W., Greider C.W., and DePinho R.A. 1998. Essential role of mouse telomerase in highly proliferative organs. Nature 392: 569.

Lessard J. and Sauvageau G. 2003. Bmi-1 determines the proliferative capacity of normal and leukemic stem cells. Nature 423: 255.

Leung C., Lingbeek M., Shakhova O., Liu J., Tanger E., Saremaslani P., van Lohuizen M., and Marino S. 2004. Bmil is essential for cerebellar development and is overexpressed in human medulloblastomas. Nature 428: 337.

Levine A.J. 1997. p53, the cellular gatekeeper for growth and division. Cell 88: 323 .

Lim D.S., Vogel H., Willerford D.M., Sands A.T., Platt K.A., and Hasty P. 2000. Analysis of ku80-mutant mice and cells with deficient levels of p53. Mol. Cell. Biol. 20: 3772.

Lowe S.W. and Sherr C.J. 2003. Tumor suppression by Ink4aArf: Progress and puzzles. Curr. Opin. Genet. Dev. 13: 77.

Lozano G. and Elledge S.J. 2000. p53 sends nucleotides to repair DNA. Nature 404: 24.

Machold R., Hayashi S., Rutlin M., Muzumdar M.D., Nery S., Corbin J.G., Gritli-Linde A., Dellovade T., Porter J.A., Rubin L.L., Dudek H., McMahon A.P., and Fishell G. 2003. Sonic hedgehog is required for progenitor cell maintenance in telencephalic stem cell niches. Neuron 39: 937.

Maier B., Gluba W., Bernier B., Turner T., Mohammad K., Guise T., Sutherland A., Thorner M., and Scrable H. 2004. Modulation of mammalian life span by the short isoform of p53. Genes Dev. 18: 306.

Maslov A.Y., Barone T.A., Plunkett R.J., and Pruitt S.C. 2004. Neural stem cell detection, characterization, and age-related changes in the subventricular zone of mice. J. Neurosci. 24: 1726.

Matheu A., Pantoja C., Efeyan A., Criado L.M., Martin-Caballero J., Flores J.M., Klatt P., and Serrano M. 2004. Increased gene dosage of Ink4a/Arf results in cancer resistance and normal aging. Genes Dev. 18: 2736.

McEachern M.J., Krauskopf A., and Blackburn E.H. 2000. Telomeres and their control. Annu. Rev. Genet. 34: 331.

Migliaccio E., Giorgio M., Mele S., Pelicci G., Reboldi P., Pandolfi P.P., Lanfrancone L., and Pelicci P.G. 1999. The p66shc adaptor protein controls oxidative stress response and life span in mammals. Nature 402: 309.

Mihaylova V.T., Borland C.Z., Manjarrez L., Stern M.J., and Sun H. 1999. The PTEN tumor suppressor homolog in Caenorhabditis elegans regulates longevity and dauer formation in an insulin receptor-like signaling pathway. Proc. Natl. Acad. Sci. 96: 7427.

Mishima K., Handa J.T., Aotaki-Keen A., Lutty G.A., Morse L.S., and Hjelmeland L.M. 1999. Senescence-associated betagalactosidase histochemistry for the primate eye. Invest. Ophthalmol. Vis. Sci. 40: 1590.

Molofsky A.V., Pardal R., and Morrison S.J. 2004. Diverse mechanisms regulate stem cell self-renewal. Curr. Opin. Cell Biol. 16: 700 .

Molofsky A.V., He S., Bydon M., Morrison S.J., and Pardal R. 2005. Bmi-1 promotes neural stem cell self-renewal and neural development but not mouse growth and survival by repressing the p16Ink4a and p19Arf senescence pathways. Genes Dev. 19: 1432.

Molofsky A.V., Pardal R., Iwashita T., Park I.K., Clarke M.F., and Morrison S.J. 2003. Bmi-1 dependence distinguishes neural stem cell self-renewal from progenitor proliferation. $\mathrm{Na}$ ture 425: 962

Morrison S.J., Shah N.M., and Anderson D.J. 1997. Regulatory mechanisms in stem cell biology. Cell 88: 287.

Morrison S.J., Prowse K.R., Ho P., and Weissman I.L. 1996a. Telomerase activity in hematopoietic cells is associated with self-renewal potential. Immunity 5: 207.

Morrison S.J., Wandycz A.M., Akashi K., Globerson A., and Weissman I.L. 1996b. The aging of hematopoietic stem cells. Nat. Med. 2: 1011.
Morshead C.M., Reynolds B.A., Craig C.G., McBurney M.W., Staines W.A., Morassutti D., Weiss S., and van der Kooy D. 1994. Neural stem cells in the adult mammalian forebrain: A relatively quiescent subpopulation of subependymal cells. Neuron 13: 1071.

Paradis V., Youssef N., Dargere D., Ba N., Bonvoust F., Deschatrette J., and Bedossa P. 2001. Replicative senescence in normal liver, chronic hepatitis $\mathrm{C}$, and hepatocellular carcinomas. Hum. Pathol. 32: 327

Pardal R., Clarke M.F., and Morrison S.J. 2003. Applying the principles of stem-cell biology to cancer. Nat. Rev. Cancer 3: 895.

Park I.-K., Qian D., Kiel M., Becker M., Pihalja M., Weissman I.L., Morrison S.J., and Clarke M. 2003. Bmi-1 is required for the maintenance of adult self-renewing hematopoietic stem cells. Nature 423: 302.

Pollak M.N., Schernhammer E.S., and Hankinson S.E. 2004. Insulin-like growth factors and neoplasia. Nat. Rev. Cancer 4: 505

Reya T. and Clevers H. 2005. Wnt signalling in stem cells and cancer. Nature 434: 843.

Reya T., Morrison S.J., Clarke M.F., and Weissman I.L. 2001 Stem cells, cancer, and cancer stem cells. Nature 414: 105.

Ruas M. and Peters G. 1998. The p16INK4a/CDKN2A tumor suppressor and its relatives. Biochim. Biophys. Acta 1378: F115.

Rudolph K.L., Chang S., Millard M., Schreiber-Agus N., and DePinho R.A. 2000. Inhibition of experimental liver cirrhosis in mice by telomerase gene delivery. Science 287: 1253.

Ruiz i Altaba A., Sanchez P., and Dahmane N. 2002. Gli and hedgehog in cancer: Tumours, embryos and stem cells. Nat. Rev. Cancer 2: 361.

Sell S. and Pierce G.B. 1994. Maturation arrest of stem cell differentiation is a common pathway for the cellular origin of teratocarcinomas and epithelial cancers. Lab. Invest. 70: 6.

Serrano M., Lin A.W., McCurrach M.E., Beach D., and Lowe S.W. 1997. Oncogenic ras provokes premature cell senescence associated with accumulation of p53 and p16INK4a. Cell 88: 593.

Sharpless N.E. 2004. Ink4a/Arf links senescence and aging. Exp. Gerontol. 39: 1751.

Sharpless N.E. and DePinho R.A. 2004. Telomeres, stem cells, senescence, and cancer. J. Clin. Invest. 113: 160.

Sharpless N.E., Bardeesy N., Lee K.H., Carrasco D., Castrillon D.H., Aguirre A.J., Wu E.A., Horner J.W., and DePinho R.A. 2001. Loss of p16Ink4a with retention of p19Arf predisposes mice to tumorigenesis. Nature 413: 86.

Sherr C.J. 1998. Tumor surveillance via the ARF-p53 pathway. Genes Dev. 12: 2984.

. 2001. The INK4a/ARF network in tumour suppression. Nat. Rev. Mol. Cell Biol. 2: 731.

Sherr C.J. and McCormick F. 2002. The RB and p53 pathways in cancer. Cancer Cell 2: 103.

Shiloh Y. 2003. ATM and related protein kinases: Safeguarding genome integrity. Nat. Rev. Cancer 3: 155.

Solari F., Bourbon-Piffaut A., Masse I., Payrastre B., Chan A.M., and Billaud M. 2005. The human tumour suppressor PTEN regulates longevity and dauer formation in Caenorhabditis elegans. Oncogene 24: 20.

Starling J.A., Maule J., Hastie N.D., and Allshire R.C. 1990. Extensive telomere repeat arrays in mouse are hypervariable. Nucleic Acids Res. 18: 6881.

Stiles B., Groszer M., Wang S., Jiao J., and Wu H. 2004. PTENless means more. Dev. Biol. 273: 175 .

Suzuki A., de la Pompa J.L., Stambolic V., Elia E.J., Sasaki T., del Barco Barrantes I., Ho A., Wakeham A., Itie A., Khoo W., Fukumoto M., and Mak T.W. 1998. High cancer susceptibility and embryonic lethality associated with mutation of the PTEN tumor suppressor gene in mice. Curr. Biol. 8: 1169.

Taipale J. and Beachy P.A. 2001. The hedgehog and Wnt signaling pathways in cancer. Nature 411: 349.

Tatar M., Bartke A., and Antebi A. 2003. The endocrine regulation of aging by insulin-like signals. Science 299: 1346.

Tyner S.D., Venkatachalam S., Choi J., Jones S., Ghebranious 
N., Igelmann H., Lu X., Soron G., Cooper B., Brayton C., Hee Park S., Thompson T., Karsenty G., Bradley A., and Donehower L.A. 2002. p53 mutant mice that display early ageingassociated phenotypes. Nature 415: 45.

Valk-Lingbeek M.E., Bruggeman S.W., and van Lohuizen M. 2004. Stem cells and cancer; the polycomb connection. Cell 118: 409.

van der Lugt N.M.T., Domen J., Linders K., van Roon M., Robanus-Maandag E., te Riele H., van der Valk M., Deschamps J., Sofroniew M., van Lohuizen M., and Berns A. 1994. Posterior transformation, neurological abnormalities, and severe hematopoietic defects in mice with a targeted deletion of the bmi-1 proto-oncogene. Genes Dev. 8: 757.

van de Wetering M., Sancho E., Verweij C., de Lau W., Oving I., Hurlstone A., van der Horn K., Batlle E., Coudreuse D., Haramis A.P., Tjon-Pon-Fong M., Moerer P., van den Born M., Soete G., Pals S., Eilers M., Medema R., and Clevers H. 2002. The beta-catenin/TCF-4 complex imposes a crypt progenitor phenotype on colorectal cancer cells. Cell 111: 241.

van Heemst D., Mooijaart S.P., Beekman M., Schreuder J., de Craen A.J., Brandt B.W., Slagboom P.E., and Westendorp R.G. 2005. Variation in the human TP53 gene affects old age survival and cancer mortality. Exp. Gerontol. 40: 11.

van Lohuizen M., Verbeek S., Scheijen B., Wientjens E., van der Gulden H., and Berns A. 1991. Identification of cooperating oncogenes in E mu-myc transgenic mice by provirus tagging. Cell 65: 737.

Vasile E., Tomita Y., Brown L.F., Kocher O., and Dvorak H.F. 2001. Differential expression of thymosin beta- 10 by early passage and senescent vascular endothelium is modulated by VPF/VEGF: Evidence for senescent endothelial cells in vivo at sites of atherosclerosis. FASEB J. 15: 458.

Vogel H., Lim D.S., Karsenty G., Finegold M., and Hasty P. 1999. Deletion of Ku86 causes early onset of senescence in mice. Proc. Natl. Acad. Sci. 96: 10770.

Vonlanthen S., Heighway J., Altermatt H.J., Gugger M., Kappeler A., Borner M.M., van Lohuizen M., and Betticher D.C. 2001. The bmi-1 oncoprotein is differentially expressed in non-small cell lung cancer and correlates with INK4A-ARF locus expression. Br. J. Cancer 84: 1372.

Wechsler-Reya R. and Scott M.P. 2001. The developmental biology of brain tumors. Annu. Rev. Neurosci. 24: 385.

Wong K.K., Maser R.S., Bachoo R.M., Menon J., Carrasco D.R., Gu Y., Alt F.W., and DePinho R.A. 2003. Telomere dysfunction and Atm deficiency compromises organ homeostasis and accelerates ageing. Nature 421: 643.

Zindy F., Quelle D.E., Roussel M.F., and Sherr C.J. 1997. Expression of the p16(INK4a) tumor suppressor versus other INK4 family members during mouse development and aging. Oncogene 15: 203. 


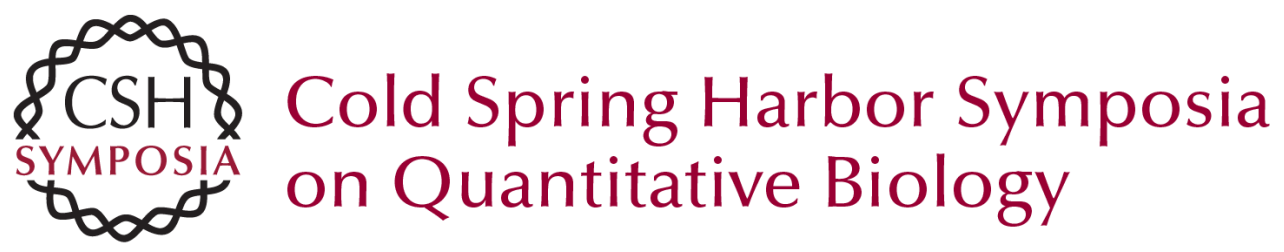

\section{Stem Cell Self-Renewal and Cancer Cell Proliferation Are Regulated by Common Networks That Balance the Activation of Proto-oncogenes and Tumor Suppressors}

R. PARDAL, A.V. MOLOFSKY, S. HE, et al.

Cold Spring Harb Symp Quant Biol 2005 70: 177-185

Access the most recent version at doi:10.1101/sqb.2005.70.057

References This article cites 103 articles, 29 of which can be accessed free at: http://symposium.cshlp.org/content/70/177.full.html\#ref-list-1

\section{License}

Email Alerting Receive free email alerts when new articles cite this article - sign up in Service the box at the top right corner of the article or click here. 